\title{
Note on gynandromorphism in the eucalyptus defoliator Thyrinteina arnobia (Stoll, 1782) (Lepidoptera: Geometridae)
}

\author{
ALINE S. BERNARDINO ${ }^{1}$, TERESINHA V. ZANUNCIO ${ }^{1}$, JOSÉ C. ZANUNCIO ${ }^{1}$, \\ ERALDO R. LIMA ${ }^{1}$ and JOSÉ E. SERRÃO ${ }^{2}$ \\ ${ }^{1}$ Departamento de Biologia Animal, Universidade Federal de Viçosa, 36570-000 Viçosa, MG, Brasil \\ ${ }^{2}$ Departamento de Biologia Geral, Universidade Federal de Viçosa, 36570-000 Viçosa, MG, Brasil \\ Manuscript received on June 27, 2006; accepted for publication on February 21, 2007; \\ presented by CARMINDA DA CRUZ LANDIM
}

\begin{abstract}
The brown moth Thyrinteina arnobia (Stoll, 1872) (Lepidoptera: Geometridae) is an important pest in Brazilian eucalyptus plantations. A gynandromorph individual of T. arnobia was found in a population of this pest in a laboratory rearing and it is described.
\end{abstract}

Key words: Thyrinteina, brown moth, gynandromorphism, eucalyptus.

The occurrence of gynandromorphism in Lepidoptera is rare. Its frequency in some species is about $0.000125 \%$, i.e., there is a gynandromorphy for every 8000 normal individuals (Josephrajkumar et al. 1998). The gynandromorphs may arise during the development of a male zygote (XX) with loss of an X chromosome or due to the fertilization of an egg with two female nuclei (Robinson 1971). Other organisms may induce gynandromorphs by infection of Wolbacchia bacteria causing female pattern in individuals genetically males (Pereira et al. 2003).

Lepidoptera gynandromorphs are more easily recognized when males and females are sexually dimorphic. The gynandromorphism is usually expressed bilaterally - an abnormal adult has half of the body typical of male and the other half typical of female (Josephrajkumar et al. 1998). On the other hand, this distinction may not be obvious in individuals with mosaic gynandromorphism, because male tissues are mixed with those of females, and in this case abnormalities are often determined only by analyses of the internal organs of these organisms.

Correspondence to: Dr. José Cola Zanuncio E-mail: zanuncio@ufv.br
The brown moth Thyrinteina arnobia (Stoll, 1782) (Lepidoptera: Geometridae) is an important pest causing significant losses in the eucalyptus crops in Brazil. This has led to a number of studies with T. arnobia including its biological control (Zanuncio et al. 1994). A gynandromorph of this species reared in laboratory conditions is herein reported and described for the first time.

Individuals of T. arnobia were maintained in the laboratory of Biological Control of Insects, of the "Instituto de Biotecnologia Aplicada a Agropecuária (BIOAGRO)" at the Federal University of Viçosa, city of Viçosa, State of Minas Gerais, Brazil for two generations. Caterpillars were reared in Eucalyptus plants or in plastic vials $(500 \mathrm{ml})$ containing fresh leaves of the host plant. The eucalyptus leaves were changed daily. Newly emerged adults were put in cages to obtain egg masses to maintain a stabilized population of T. arnobia in laboratory conditions as well to support experiments of biological control.

Thyrinteina arnobia is sexually dimorphic: females have longer wingspan, filiform antennae and light coloration (Figure 1) while males have smaller wingspan, pectinated antennae and brown to black color (Figure 2). 

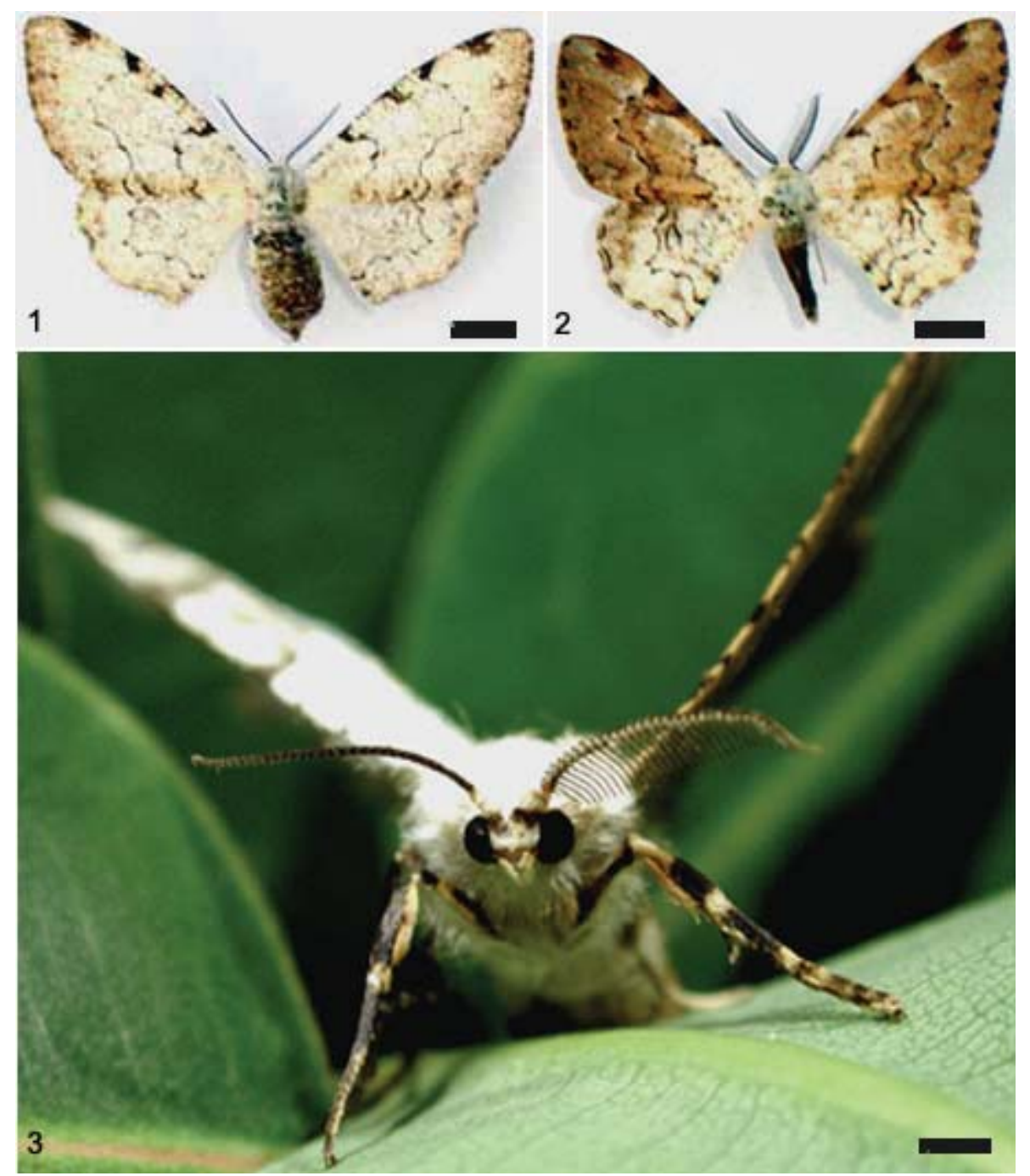

Fig. 1 - The normal Thyrinteina arnobia female. Note wing coloration and filiform antennae. Scale bar $=0.5 \mathrm{~cm}$. Fig. $2-$ The normal Thyrinteina arnobia male. Note wing coloration and pectinated antennae. Scale bar $=0.5 \mathrm{~cm}$. Fig. 3 - The Thyrinteina arnobia gynandromorph. Note the male characters (brown wings, larger eyes and pectinated antenna) on the left side and female characters (clear wings, filiform antenna and smaller eyes) on the right side. Scale bar $=0.1 \mathrm{~cm}$.

The gynandromorphy of T. arnobia was found during normal procedures of removing adults from the plastic vials to the reproduction cage. This individual is a bilateral gynandromorph with male characters such as brown wings, large eyes, pectinated antennae and short wingspan on the left side, and longer wingspan, light wings, filiform antennae and smaller eyes on the other side (Figure 3), typical of female phenotype.

The reproductive system of the gynandromorph of
T. arnobia was not studied because no other abnormal individuals were obtained.

The voucher specimen is deposited at Museu Regional de Entomologia (UFVB), Universidade Federal de Viçosa (UFV), in Viçosa, Minas Gerais State, Brazil.

It was not possible to identify the lab conditions that induced a gynandromorphy in T. arnobia. It occurred in a single individual among thousands of insects reared under natural conditions, without artificial diets or abrupt 
variations of temperature and relative humidity.

\section{ACKNOWLEDGMENTS}

To "Conselho Nacional de Desenvolvimento Científico e Tecnológico (CNPq)", "Coordenação de Aperfeiçoamento de Pessoal de Nível Superior (CAPES)" and "Fundação de Amparo à Pesquisa do Estado de Minas Gerais (FAPEMIG)".

\section{RESUMO}

A mariposa marrom Thyrinteina arnobia (Stoll, 1872) (Lepidoptera: Geometridae) é uma praga importante em plantios de eucalipto no Brasil. Um indivíduo ginandromorfo de T. arnobia foi encontrado em uma população desta praga em criação de laboratório e descrito nesta nota.

Palavras-chave: Thyrinteina, mariposa marrom, ginandromorfo, eucalipto.

\section{REFERENCES}

JOSEPHRAJKUMAR A, SUBRAHMANYAN B AND RAMAMURTHY VV. 1998. Gynandromorph of Helicoverpa armigera (Lepidoptera: Noctuidae). Ent News 109: 288292.

Pereira RAS, Prado AP And KJellberg F. 2003. Gynandromorphism in pollinating fig wasps (Hymenoptera: Agaonidae). Ent News 114: 152-155.

Robinson R. 1971. Lepidoptera Genetics. Oxford, Pergamon Press, 321 p.

ZANUNCIO JC, NASCIMENTO EC, GARCIA JF AND ZANUNCIO TV. 1994. Major lepidopterous defoliators of eucalypt in southeast Brazil. For Ecol Manage 65: 53-63. 